\title{
30
}

\section{Institutional Leadership: past, present, and future}

\author{
Marvin Washington, Kimberly Boal and John Davis
}

\section{INTRODUCTION}

Since the early writings of DiMaggio and Powell (1983), Meyer and Rowan (1977) and Zucker (1987), many insights have been gained under the broad umbrella of institutional analysis. Constructs such as "isomorphism', 'de-coupling', and 'coercive pressure', are now mainstream in much organizational theorizing. Recently, there have been new terms coined to describe the growing interest in agency in institutional analyses. Now, it not uncommon to see phrases such as 'institutional strategy' (Lawrence, 1999) and 'institutional entrepreneurship' (DiMaggio, 1988; Suddaby and Greenwood, 2005), to describe the behavior of individuals and organizations that are attempting to change the institutional landscape in a particular environment. In this chapter, we continue this line of inquiry, not by going forward, but by stepping back and highlighting the contribution early work on examining agency in institutional analysis. Here, we discuss and extend ideas around institutional leadership.

It has been 50 years since Selznick published his seminal work Leadership in
Administration. Many scholars have credited this work with ushering in discussions of institutions as 'organizations infused with value'. However, not only did Selznick describe how organizations become institutions, but he also described the characteristics of leaders of these organizations. Projects have since examined institutional leadership (e.g., Kraatz and Moore, 2002). Institutional leadership, ' the promotion and protection of values' (Selznick, 1957: 28) is different from traditional leadership: 'task and person-oriented behaviors of leaders as they attempt to provide guidance, support, and feedback to subordinates' (Boal and Schultz, 2007). It is the concept of institutional leadership that we examine in this article.

In this article, we do three things. First, we discuss Selznick's original ideas about institutional leadership and the role they play in institutionalization processes. We also review the trajectory of his work, by examining the work in the organizations and institutions literature that have built upon Selznick's ideas. Second, we extend his work by examining the three functions of institutional leaders. First, they manage the internal consistency of 
the firm (Selzick's notion of commitment to the values and mission of the organization). Second, they develop external supporting mechanisms to enhance the legitimacy of the organization. Third, institutional leaders, overcome external enemies. We conclude by suggesting a reconciliation between institutional leadership and the work on traditional (or organizational) leadership. Our core argument is that organizational leadership, or leaders inside of organizations, is(are) based upon a notion of instrumental agency, hierarchical and charismatic power, and typically uses a future leaning vision. Institutional leadership, or leaders of organizations, is(are) based upon a notion of embedded or constrained agency, influence or negotiated power, and typically uses a backward-leaning vision meaning that the vision is there to remind the organization of the core values.

\section{SELZNICK'S VIEWS OF INSTITUTIONAL LEADERSHIP}

Most scholars know of Selznick's work Leadership in Administration as providing the famous definition of institutions as organizations 'infused with value'. However, this is a secondary concern with his work. Selznick's primary objective in Leadership in Administration is to understand the behaviors and characteristics of those who lead institutions and how these behaviors are different than the behaviors of those who lead organizations. In Selznick's own words 'The argument of this essay is quite simply stated: The executive becomes a statesman as he makes the transition from administrative management to institutional leadership' (1957: 4). This leads to his discussion of institutionalization as a process; organizations become institutions over time. The degree of institutionalization depends upon the potential conflict between the leader's goals and group's goals; the more precise an organization's goals and the more specialized and technical its operations, the slower the institutionalization process. Thus, to institutionalize an organization is to infuse with value beyond the technical requirements of the task at hand (1957: 17).' This 'infuse with value' statement is closely connected with an organization's concern with self-maintenance (the organization's desire to maintain its existence beyond the technical requirements of the organization). Note the active nature of the word institutionalize. Selznick is suggesting the process of institutionalization is a process that occurs as leaders respond to the internal and external forces that are placed upon organizations.

After, describing what Selznick means by institution, as opposed to organization, he returns to his primary objective of describing the role of institutional leaders in this process. 'Most of this essay will be devoted to identifying and analyzing the chief functions of institutional leadership' (1957: 22). He distinguishes the institutional leader as separate from the interpersonal leader (what might be described as the charismatic or transformational leader). The interpersonal leader's task is 'to smooth the path of human interaction, ease communication, evoke personal devotion, and allay anxiety' (1957: 27). The institutional leader's task however is 'the promotion and protection of values' (1957: 28).

The first task Selznick describes is the creation and maintenance of the organization's character. Selznick suggests that leading an institution:

is far more than the capacity to mobilize personal support; it is more than the maintenance of equilibrium through the routine solution of everyday problems; it is the function of the leader-statesman whether ofa nation or a private association - to define the ends of group existence, to design an enterprise distinctively adapted to these ends, and to see that the design becomes a living reality. These tasks are not routine; they call for continuous self-appraisal on the part of the leaders; and they may require only a few critical decisions over a long period of time. (1957: 37)

It is these few critical decisions that create an organization's character. 
The development of an organization's character is a necessary step in the institutionalization process of organizations. 'The study of organizational character-formation is, then, a phase of institutional analysis. Here the emphasis is on the embodiment of values in an organizational structure through the elaboration of commitments - ways of acting and responding that can be changed, if at all, only at the risk of severe internal crises' (1957: 40). To expand upon this point further, Selznick draws upon his examples as diverse as the Tennessee Valley Authority (Selznick, 1949) and the Bolshevik Party (Selznick, 1952).

Selznick summarizes his arguments about institutional leadership by suggesting that the function of institutional leadership is inherently political. 'We have argued that policy and administration are interdependent in the special sense that certain areas of organizational activity are peculiarly sensitive to policy matters. Because these areas exist, creative men are needed ... These men are called leaders; their profession is politics' (1957:61). However, he is not referring to the political or power sense of the word politics but politics in the sense of consensus.

\section{EXTENSIONS OF SELZNICK'S WORK}

A search of 'Leadership in Administration' on Google Scholar generated over 750 citations. Of those citations, 170 have been in Academy of Management Journal, Strategic Management Journal, Administrative Science Quarterly, Organization Studies, Human Relations, Organization Science, and Journal of Management Studies. Ironically, fewer than 10 of the 750 citations were in Leadership Quarterly (more on that later). In this section, we examine how Selznick's ideas on institutional leadership have been extended in the current literature. After that, we speculate as to why Selznick's concept of institutional leadership hasn't been more prominent in the leadership literature: our brief answer is that Selznick is concerned with leadership of organizations and the leadership literature is concerned with leadership inside organizations.

\section{Extensions that do not deal with leadership}

Most of the citations to Selznick's 1957 book are not about institutional leadership. Though our search and analysis was not exhaustive, from the articles that we did review, the typical citation to Selznick's work is his description of institutions as organizations infused with value (Selznick, 1957: 17). Another major part of the literature that builds on Selznick is his work on organizational commitments. Of the work that focuses on institutional leadership, the top management team literature refers to Selznick often. For example, in their work on cognitive and affective conflict, Amason and Sapienza (1997) argue that greater agreement among the top management team, the less the affective conflict. They draw this support from Selznick's argument that 'a central function of top management is to create super-ordinate goals that unite action and to reward cooperative behavior towards those goals' (Amason and Sapienza, 1997: 502). This is similar to the other work on top management teams that draws from Selznick.

\section{The leadership extensions}

It is the work of Kraatz and Moore that most exemplifies the extensions of Selznick's work on institutional leadership. Kraatz and Moore's (2002) study examines the role of leadership migration in the institutional changes of liberal arts college education. They argued that except for a few theoretical statements about the role of leadership in institutional change and the rare empirical exception (Hirsch, 1986; Leblebici, Salancik, Copay and King, 1991), the role of leadership in institutional change has been neglected over the past 40 years. Drawing from 
Selznick's statement that a critical component of institutionalization is the selection of leaders from a homogeneous pool of candidates, Kraatz and Moore examine three mechanisms of how leadership changes leads to institutional change: (1) knowledge transfer and interorganizational learning; (2) introduction of new mental models and assumptions; and (3) attenuation or replacement of institutional values (2002: 123). Kraatz and Moore find support for their hypotheses regarding the factors that allow leadership migration to impact organizational change.

While this represents an exemplar in the extension of Selznick's work, other scholars have also contributed to a better understanding of institutional leadership. In a wonderful study examining the role of CEOs, Tengblad builds upon Selznick's conception of the institutional leader by defining the role of the CEO as managing internal and external expectations. In a replication of work by Sune Carlson (Carlson, 1951), Tengblad observed 8 CEOs for a total of 159 days. He directly followed CEOs around for 26 days (more than 300 hours) and had the CEOs conduct self-recordings of themselves for 133 days. Tengblad focused his study on understanding how CEOs handled financial expectations. One of his key findings was the increasing use of organizational culture as a management and communication tool. 'Messages about the desired state of affairs (formulate, for instance, as 'ten commandments', 'cornerstones', 'business mission' or 'corporate vision') were transmitted through booklets and brochures in most companies. During the observations the CEOs made numerous efforts to spread these messages' (Tengblad, 2004: 592). Tengblad argued that the CEOs in his study often resorted to using the mission of the organization as a way of communicating the financial expectations. The CEOs did not just want to paint a 'rosy picture' but wanted to demonstrate that they were doing all they could to improve their financial outlook. Internally, Tengblad found that the CEOs used a variety of assessments to evaluate the senior managers. These assessments created a 'carrot and stick' (2004: 596) approach to managing internal expectations. Similar to Selznick's original conclusions, Tengblad concluded that the CEOs in his study spent enormous energy in managing the external expectations of their organizations. However, this management process did not automatically lead to changes to the organization.

By bringing institutional leadership back to the forefront of institutional analysis, we argue that institutional leadership might be the reconciliation between the first wave of institutional analysis which were more interested in a deterministic view of institutionalized action (DiMaggio and Powell, 1983) and the calls for a more agentic view of institutions (Hirsch and Lounsbury, 1997). Recently, authors have been calling attention to a middle ground of institutionalized action; institutional work (Lawrence and Suddaby, 2006). By institutional work, the concern is on how institutions maintain their status and legitimacy in the face of their own institutionalized environment. We argue that the institutional leader's role in maintaining the legitimacy of their institutions warrants renewed attention.

\section{SO WHAT DO INSTITUTIONAL LEADERS DO?}

We argue that institutional leaders do three things to maintain the legitimacy and survival of their institution. The first is that they manage the internal consistency of the organization. This extends Selznick's concepts of leaders maintaining internal commitment to the organizational values and mission. The second is that institutional leaders develop external supporting mechanisms that lead to increasing legitimacy of their organization (the how organizations become institutions). The third activity that institutional leaders engage in is actions to overcome external enemies. 


\section{Internal consistency}

It is clear that institutional leaders play an active role in developing the vision and mission of the organization. However, while some scholars view the vision setting process as a strategic or organizational function (Boal and Schultz, 2007; Nutt and Backoff, 1997), from an institutional perspective, vision setting is also inherently political. Organizational visions give rise to stories, myths, and ceremonies (Meyer and Rowan, 1977); they enable the organization to remember the 'good old days' or to reinforce some key values of the organization (Bolman and Deal, 2003). Selznick describes one task of institutional leadership that helps in the institutionalization process as 'the elaboration of socially integrating myths' (1957: 151). These myths are used to help 'infuse day-to-day behavior with long-run meaning and purpose' (1957: 151).

Gregory Berry (2001) notes, 'Stories are a fundamental way through which we understand the world .... By understanding the stories of organizations, we can claim partial understanding of the reasons behind visible behavior' (2001: 59). As such the exchange of stories, rather than merely routines, allows participants to develop a new 'collective story' through which they can become a social learning system. Stories are thus an important part of establishing internal consistency. Balancing the past, present, and future through storytelling is an essential skill for institutional leaders who hope to promote it. It is in the creating, telling, and retelling of key stories by institutional leaders that the past, the present, and the future of the organization are connected.

Creating and seizing upon ceremonies are also in important part of maintaining internal consistency (Bolman and Deal, 2003). A great example of this is a speech given by Douglas McArthur. General Douglas MacArthur's farewell address to the Corps of Cadets at West Point, May 12, 1962, illustrates how institutional leaders symbolically shape behaviors of individuals by capitalizing on an important ceremonial tradition, the annual presentation of the Thayer Award (James, 1985: 678). 'Duty, Honor, County' the cadet motto (Thomason, 1971: 43) - powerfully defines historical identity and guides behavior for the cadets of the U.S. Military Academy and for graduates of the USMA for the rest of their lives (Boal and Schultz, 2007; Ellis and Moore, 1974):

\begin{abstract}
Duty, honor, country: Those three hallowed words reverently dictate what you want to be, what you can be, what you will be. They are your rallying point to build courage when courage seems to fail, to regain faith when there seems to be little cause for faith, to create hope when hope become forlorn .... The code which those words perpetuate embraces the highest moral law .... Its requirements are for the things that are right and its restraints are from the things that are wrong .... The long, gray line has never failed us. Were you to do so, a million ghosts in olive drab, in brown khaki, in blue and gray, would rise from their white crosses, thundering those magic words: Duty, honor, country. (Duffy and Carpenter (1997: 197-200)
\end{abstract}

This speech is an example of institutional leadership in two ways. The first is by noticing what was not said. MacArthur's speech was more about character, mission, values of the organization (hence its institutional character) than it was about tactics. Second, this speech has been 'retold' countless times, reinforcing the military's commitment to these values. For example, each year New Cadets at the USMA are issued a personal copy of Bugle Notes (Thomason, 1971). One of the coauthors' personal copy, which he received on his first day at the USMA, contains this dedication:

To the men who join the corps in 1971, 169 years after its beginning, this book is dedicated. Bugle Notes is the story of the Long Gray Line. Within these pages can be found the reasons for the greatness and esprit of those who have graduated from West Point. Herein lie the relationships of the corps to the United States, the Army, and itself. These are the traditions held sacred by every West Pointer; they are your heritage. Cherish them, and pass them on to those who will follow after you. (1971: 1)

In the heart of this copy of Bugle Notes (Thomason, 1971: 108-118) is printed the 
complete text of MacArthur's speech, a deliberate effort to infuse with value the army of the future by connecting it to the army of the past.

We suggest that institutional leaders take part in building an autobiographical pattern of historical accounts of their organization to produce a coherent picture of an organization's identity, their own roles within their organization, and the realities of organizational life while also preparing the organization to effectively respond to future environmental changes. There are a number of possible ways in which institutional leaders might organize events into a coherent pattern producing an overarching institutional narrative. In their work on the individual-level life story construct, Bluck and Habermas (2000) suggest thematic coherence, as an important part of the individual and institutional story creation process.

Thematic coherence is useful in comprehending periods of organizational transition, such as Andrew Grove's concept of strategic inflection points (1996, 1997). 'Strategic inflection points are caused by fundamental industry dynamics, technologies, and strategies that create new opportunities for institutional leaders to develop new visions, create new strategies, and move their organizations in new directions as they traverse through turbulence and uncertainty' (Boal and Hooijberg, 2000: 520). Strategic inflection points may be virtually impossible to detect a priori, but by maintaining thematic coherence, institutional leaders impose their own sense on successes and failures in the face of extreme uncertainty.

One theme that is frequently used by institutional leaders to establish meaning for their followers is the concept of the hero's journey. Coined by Joseph Campbell in his book, The Hero with a Thousand Faces (1972), he argued that all myths, regardless of the culture that produced them, shared the same basic narrative features and structure. Central to his view of myth is the figure of the hero, his or her journey or struggle in adventure, and eventual return or arrival in victory. Shamir and his colleagues (2005), in their analysis of the narrative accounts, found that the theme of struggle was common among leaders. Through battles and ordeals, leaders saw themselves transformed, thereby attaining the power to assume the task of leadership. One of the insights that Bluck and Habermas (2000) provide is that one source of an individual's motivation is the sense of self that the life story provides. The themes and order that structure life events in the creation of the life story schema set the rationale for behavior across time, and guide future goals and actions by their linkage with that life story model.

Beyond being an expression of their own identity, institutional leaders use their life stories in an effort to influence their followers, by framing expectations and impressions, serving as a role model, showing the legitimacy of their leadership role, and shaping collective expectations and meanings (Shamir et al., 2005). By extension, a shared organizational life story provides the inspiration for collective behavior among members by connecting it with the past through the organization's history. In establishing the rationale behind the organization's life story, the schema generates an organizational identity that insures continuity between past and future goals and actions. Looking at the development of an effective leader vision, Strange and Mumford (2005) found that vision emerged in a process where leaders reflected on the fortunes of past goals and behaviors in deriving mental models for the future. The vision formation process causes leaders to use a descriptive mental model of the organization - one that articulates the themes and relationships between actions and outcomes - and by assessing that model in light of organization members' experience, to then devise a prescriptive model for situations yet to be encountered. Storytelling and the coherence demanded by the structure of the life story schema combine in the ongoing vision formation process occurring within organizations. 
The enduring values, expectations, and responsibilities that maintaining coherence produces for the organization - and which are manifested in its vision - show the opportunity that institutional leadership has in defining an organization's approach to future circumstances. Although all individual members are 'coauthors' of an organization's life story (Czarniawska, 1997: 14), powerful individuals, such as institutional leaders, can produce narratives for which the rest of the organization is more of a passive audience. Control over storytelling and the way members interpret an organization's path over time allows control over the vision formation process, and should significantly influence the character and effectiveness of organizational mission. Although many individuals may possess experience relevant to the development and evaluation of past mental models of the organization, institutional leaders have a unique position from which to influence this critical feedback mechanism in the vision-formation process. The background and past experiences of the leader is influential in developing descriptive mental models and the leader's experience with those models as they confront the demands of current organizational situations influences their current mental models.

An institutional leader's own life story, thus, enters into the vision formation process along with the life story of the organization itself and its members. The requirement for coherence in both organizational and leader life stories means that a institutional leader imparts much of their own meaning and sense-making onto the organization; actions and events are interpreted through the lenses of thematic and causal coherence in the context of the histories of both the organization and the institutional leader. When Jack Welch was the head of General Electric, he taught a course on Leadership and Values seven times a year to high-potential middle managers. In addition, courses were taught by the vicechairman and the CFO. In fact, corporate leaders taught 60 percent of the senior-level courses, with Welch often standing in front of the group (Greiner, 2002).

\section{External supporting mechanisms}

Another task that institutional leaders perform is to develop external supporting mechanisms in order to maintain survival and obtain legitimacy for the organization. Organizational survival requires maintaining a balance between stability and flexibility (Brown and Eisenhardt, 1998). Vision setting and storytelling are excellent mechanisms to maintain internal consistency and produce stability in an organization. Without stability a firm would not be able to accumulate knowledge, and would be in a constant state of flux never being able to move any distance from its original founding because the organization would have no basis to evaluate every new fad. Institutional leaders over this inertia problem by serving as cognitive network brokers (Burt, 1992). By interaction with a wide range of networks, inside and outside the boundaries of the firm, individuals are encouraged to bring new ideas/schema to old problems as well as discover new problems to which known or knowable shared schema can be applied (Kraatz and Moore, 2002).

One of the ways that institutional leaders ensure their survival is to maintain their legitimacy. In Suchman's (1995: 574) definition, legitimacy is the 'generalized perception that the actions of an entity are desirable, proper, or appropriate within some socially constructed system of norms, values, beliefs and definitions.' Institutional theory helps us to understand that as companies are embedded in the economic and institutional environment, we can infer the cultural meanings, ideals and norms that have been socially accepted in a society. These norms can be seen as flexible guidelines that companies must maintain in order to achieve congruence with society and in the legal environment.

Organizations and their associated practices are built upon three types of legitimacy (Scott, 2001). A new practice is normatively legitimate when it is consistent with wider societal values. Regulatory legitimacy is conveyed when existing rules and laws support a new practice. A new practice is 
culturally/cognitively legitimate when it is connected to wider belief systems inside of the institutional environment. When an organization is endorsed and supported by a segment of society large enough to ensure its effectiveness and survival it can be considered to be legitimate (Pfeffer and Salancik, 1978), and as such, the organization only needs to be supported by a segment of a population in order to remain legitimate in the presence of attacks from external sources. As organizations utilize socially acceptable procedures to conduct potentially controversial activities, the organization can manage the impression that it is rational and legitimate (Scott, 1987).

Selznick himself recognized the relationship between institutional leaders and the legitimacy of the institution they are attempting to lead. To understand the nature of institutional leadership, we must have some notion of the meaning and significance of the term 'institution' itself' (1987: 4). This leads to the discussion of the differences between institutions and organizations. Organizations are 'a rational instrument engineered to do a job' (1987: 5). An institution is 'a natural product of social needs and pressures - a responsive, adaptive organism' (1987: 5). The pressures of institutions come from two sources: external, or the wider environment, and internal, or the inner workings of the organizations. Using examples of the military and the Catholic Church, Selznick describes how these pressures produce administrative ideologies useful as communication and self-defense techniques, the creation and the protection of elites, and the emergence of contending interest-groups. Selznick argues that the diversity of forces has a unifying effect in that they define the 'commitments of the organization and give it a distinctive identity' (1957: 16).

Rao (2002) also identifies strong individuals as 'evangelists' for a practice, alluding to the significant of a singular powerful actor who drives the legitimation of a practice much like a religion or ideology. Rao's terminology most aptly signifies an important component of institutional leadership at the individual level, specifically, the strong adherence to a set of principles that drive the actions of the individual. These pieces (among others) serve to identify and construct the external version of an institutional leader - an individual who utilizes institutional supporting mechanisms, existing governance mechanisms and cognitive frameworks to alter power arrangements through explicit institutional strategies.

In a recently published dissertation, Patterson (2007) extends the idea of institutional leader as evangelists in her examination of D.D. Palmer and his efforts to create the field of chiropractic medicine. She examined how Palmer created Palmer Chiropractic College to gain legitimacy for chiropractic medicine. Her work shows the link between the creation of chiropractic colleges and the growing support and cognitive legitimacy of chiropractic medicine.

Drawing from the work in institutional theory, we argue that institutional leaders perform two tasks to gain external legitimacy for their institution. First, institutional leaders develop supporting mechanisms (Washington and Ventresca, 2004) that help to maintain their existence and sustain the acceptance and use of the practice. These supporting mechanisms commonly take the form of state or normative support for particular practices. Drawing from Scott's three pillars of institutionalism, these practices could be the development of an association, interest group, or lobbying group to impact the normative or regulative aspects of the environment

The second process recalls the major contribution of Berger and Luckman (1967) in that institutional leaders strive for widespread social acceptance of their organization. Stigmatized practices are very difficult to institutionalize because they are generally contested. This aspect provides boundaries to tease apart how an organization might have established supporting mechanisms yet never gain widespread social acceptance (prostitution, drug use, and same-sex marriage would be examples of such institutions). 
An example of this type of institutional work would be the efforts of Captain Palmer E. Pierce. As the first president of the National Collegiate Athletic Association (NCAA), he worked to eliminate the violence in college football which was causing numerous deaths (Falla, 1981). The violence in football was so bad, that many schools abandoned the sport or switched to the less violent sport of rugby (Smith, 1988). His efforts not only helped to reduce the violence, but also helped to grow the membership of the NCAA. Founded in 1906 with only 38 member schools, by 1942, the NCAA had 314 schools which included 'nearly every college or university of importance in the country' (Stagg, 1946: 81).

\section{Overcome external enemies}

The final task of institutional leadership is overcoming external enemies. Institutions don't exist in a vacuum. Friedland and Alford (1991) suggest that organizational fields operate under diverse belief systems that differ fundamentally in their content, as well as the nature of central assumptions and ordering principles that they refer to as institutional logics. However, Washington, Forman, Suddaby, and Ventresca (2005) argue that there could be multiple institutions competing for control over the organizational field. These competing institutions have different sources of interest and identities. Much like the institutional leaders of the NCAA defending their institutions against the NAIA, AAU, and AIAW (Washington, 2004; Washington, Forman, Suddaby, and Ventresca, 2005) we argue that institutional leaders also have to defend against external enemies.

Where will the attack come from? First, we argue that leaders have to defend against the death of their existing practice. Oliver (1992: 581) argues that 'threats to the persistence of an institutionalized practice may be explained by a decline in.... the functional necessity of the practice.' These threats can come from political pressures (changes in laws, or regulations) technical pressures (innovative practices) or social practices (other organizations have stopped performing the practice). Patterson (2007) identified the attacks on chiropractic medicine as coming from traditional medicine in the form of basic science laws. These laws were put in place as a form of regulation against anyone practicing medicine; all medical practitioners regardless of specialty had to pass a set of science requirements that the traditional medicine community knew chiropractors could not pass.

Another attack comes from fragmentation of the population that originally institutionalized the practice (Zucker, 1987). Institutions are only legitimate for a given population or segment of society. If the population splits, either politically as organizations within the population fight over jurisdiction, or socially, the supporting populations create niche populations, then support for that practice may wane. We also argue, extending the work of Zucker (1987) and Greve (1995), that an organizational practice comes under attack as other actors choose to invest in a competing practice. Here we contend that there is competition among practices to become institutionalized. Thus, if a set of actors decide to institutionalize a second practice, this might in fact de-institutionalize the first practice.

In short, we argue that institutional leaders are involved in their own institutions work of maintaining survival. The activities of the institutional leaders range from vision setting, storytelling, network brokering to defending the practices of their institution. Future research could empirically test these ideas by examining the practices of institutional leaders. In the next section we return to one problem that plagued us as we conducted our literature review of institutional leadership; why is there a lack of institutional leadership ideas in the leadership literature?

\section{Reconciling leadership research with leadership in administration}

A surprising result of our review of how Selznick's work has been cited in 
management research was the relative absence of Selznick's work in the traditional leadership literature. Of the more than 750 citations to Selznick's work, fewer than 10 were from Leadership Quarterly - the preeminent journal focused on leadership. This is surprising to us given that all of the articles in The Leadership Quarterly are about leadership. Yet we found only 10 articles out of more than 250 articles published since the founding of The Leadership Quarterly that even cited Selznick and usually he was not central to their arguments.

Selznick's work is similarly absent in other leadership texts. Stogdill's classic Handbook of Leadership (1974: 28) contains only one mention of Selznick, a single sentence listing Selznick among those who treat address leadership by classifying its functions. Yukl's (2002) advanced leadership textbook, Leadership in Organizations, contains no mention of Selznick (1957). Not only is there a relative lack of Selznick in the academic literature, but there is also a lack of Selznick in leadership textbooks. Using an admitted convenience sample of two popular organizational behavior textbooks, we found the following: Robbins and Judge's (2007) Organizational Behavior contains two chapters (of nineteen) on leadership and classifies both chapters at the group level of analysis. Robbins and Judge contains no mention of Leadership in Administration. Similarly, a 'core concepts' organizational behavior textbook, Schermerhorn, Hunt, and Osborn's (2004) Core Concepts of Organizational Behavior contains one chapter (of nineteen) on leadership, considers leadership as an organizational process, and does not mention Selznick in its index at all.

Perhaps the problem is the traditional academic classification of leadership as an organizational behavior topic. Considering the perspective in Selznick (1957), maybe we would be better off to consult the treatment of leadership in organization theory textbooks. However, we found similar results in a similar sample of popular organization theory textbooks. Daft's Organization Theory and
Design (2004) has no chapter (of thirteen) primarily on leadership, considers leadership primarily as a process, and does not mention Selznick in its index at all. Bolman and Deal's (2003) somewhat less traditional Reframing Organizations has one chapter (of twentyone) dealing primarily with leadership, takes a less traditional integrative perspective on leadership, and mentions Selznick only in conjunction with a discussion of the symbolic frame of organizational culture.

Leadership studies have enjoyed a renaissance in the past two decades, thanks primarily to the shift to the transformational/charismatic perspectives (Hunt, 1999). Yet a partial result of this renaissance has been what Hunt and Dodge (2000) called 'leadership déjá vu all over again.' That is, neglect of historical antecedents in the leadership literature has caused an overemphasis on concepts that exploit the spirit of the times. Less charitably, this neglect generates leadership fads. Similarly, Bedeian and Hunt (2006), in a recent effort to tease out essential differences between leadership and management, went even further, questioning whether the long-standing confusion between leadership and management in both popular and academic understandings of leadership has led to the need for a complete reconceptualization of leadership. Selznick's (1957) work may thus be positioned for another 'shot' at influencing the field of leadership.

Lowe and Gardner (2000), in their summary and evaluation of the first ten years of The Leadership Quarterly categorized the articles from that journal's first decade in to the following categories: trait theories, behavioral theories, contingency theories, multiple-level approaches, neo-charismatic approaches, leadership and information processing, other prominent approaches (e.g., romance of leadership, top management teams), and new directions (e.g., political leadership, strategic leadership). Their table (2000: 477-479) of leadership paradigms and theories identified only one article on institutional theory and classified it among 'other prominent approaches.' 
In the early days of The Leadership Quarterly, however, there was a strong 'taste' for institutional leadership. Birnbaum's (1990) article, published in the first volume of The Leadership Quarterly, was an excellent analysis of how college and university presidents assessed their own effectiveness. The question goes to the heart of our argument that institutional leaders create external supporting mechanisms and overcome external enemies. He found that the presidents in his sample used institutional performance and constituent (key stakeholders) satisfaction. For our purposes, this article represents the type of work that we think there should be more of. More work on institutional leaders needs to examine the processes by which leaders lead organizations, not examine the traits, behaviors, and characteristics of leaders.

We, along with others, argue that the lack of inclusion of Selznick's work on institutional leadership is due to leadership's focus on leadership inside of organizations (Biggart and Hamilton, 1987; Boal and Hooijberg, 2000; Dubin, 1979; Hunt, 1999; Selznick, 1984). 'Theories of leadership have tended to focus on the characteristics of leaders, on the behaviours leaders exhibit, or on the situational factors that determine effective approaches to leadership. Early research on leadership attempted to identify th attributes of great leaders, such as Napolean and Washington, that set them apart from 'lesser' persons (Biggart and Hamilton, 1987: 430-431)'. The leadership literature classifies these types of studies as supervisory theories of leadership. 'Supervisory theories of leadership, (e.g., path-goal, contingency, Leadership Menber Exchange) focus on tasks and person-oriented behaviour of leaders as they attempt to provide guidance, support, and feedback to subordinates' (Boal and Hooijberg, 2000). While institutional leadership is concerned with the leadership of organizations.

Table 30.1 summarizes our arguments about the relationship of institutional leadership and organizational leadership. We have argued that institutional leaders operated within an embedded agency perspective. While actions are not totally determined by the institutional constraints of the organization, these missions and values of the institution do reduce the degrees of freedom of the leader. An organizational leader however, is less constrained. In much research, it is the risk-taking part of being a leader - stepping outside of the organizational boundaries that is often the difference between managers and leaders (Hacker and Washington, 2007). The view of constrained agency is connected to the tactics of influence and negotiation for the institutional leader. Keeping the institution on track requires the institutional leader to develop political skills. This is in sharp contrast to the organizational leader that uses either their position or their charisma to 'get things done'.

One of the sharpest distinctions between institutional leaders and organizational leaders is their use of a vision statement. For an institutional leader, the vision is a chance to embed the values and mission of the organization into the everyday reality. For an organizational leader, the vision is a chance to look forward to future challenges and developments.

In this section we argue that both the leadership literature and the institutional theory literature can benefit from a return to Selznick's ideas about institutional leadership. Most scholars would put Selznick in the 'old institutional theory' category. However with the growing calls to incorporate more agency in new-institutional studies (Hirsch and Lounsbury, 1997) Selznick's ideas might offer a theoretical advance of the current institutional theory literature. The old literature on institutional theory used to focus on concepts of isomorphism, legitimacy and diffusion. While these are three different ideas, they all share a common trait in that you can examine issues of isomorphism, legitimacy, and diffusion with out looking inside of the organization. All three ideas lend themselves wonderfully to the "now legitimate' use of event history analysis where researchers develop variables that measure 
Table 30.1 Summary differences between institutional leadership and organizational leadership

\begin{tabular}{|c|c|c|}
\hline $\begin{array}{l}\text { Differences between the } \\
\text { two concepts }\end{array}$ & Institutional leadership & Organizational leadership \\
\hline Type of agency & $\begin{array}{l}\text { Muted, constrained 'Here the } \\
\text { emphasis is on the embodiment } \\
\text { of values in an organizational } \\
\text { structure through the elaboration } \\
\text { of commitments - ways of acting } \\
\text { and responding that can be } \\
\text { changed, if at all, only at the risk } \\
\text { of severe internal crises' (Selznick, } \\
1957: 40 \text { ) }\end{array}$ & $\begin{array}{l}\text { Instrumental, rational 'Early research } \\
\text { on leadership attempted to identify } \\
\text { the attributes of great leaders, } \\
\text { such as napoleon and Washington, } \\
\text { that set them apart from 'lesser' } \\
\text { persons' (Biggart and Hamilton, } \\
\text { 1987: 430-431) }\end{array}$ \\
\hline Power & $\begin{array}{l}\text { Influence, negotiation 'Because } \\
\text { these areas exist, creative men } \\
\text { are needed ... these men are called } \\
\text { leaders; their profession is politics' } \\
\text { (Selznick, 1957: 61) }\end{array}$ & $\begin{array}{l}\text { Hierarchical, charismatic 'supervisory } \\
\text { theories of leadership ... focus } \\
\text { on tasks and person-oriented behaviour } \\
\text { of leaders as they attempt to provide } \\
\text { guidance ... to subordinates' (Boal } \\
\text { and Hooijberg, 2000) }\end{array}$ \\
\hline The role of vision & $\begin{array}{l}\text { Reconnect the organization to the } \\
\text { original values 'The promotion and } \\
\text { protection of values' } \\
\text { (Selznick, 1957: } 28 \text { ) }\end{array}$ & $\begin{array}{l}\text { Move the organizational forward } \\
\text { to new goals and challenges }\end{array}$ \\
\hline
\end{tabular}

institutional concepts and then examine how these variables impact the adoption of a particular factor that represents legitimacy, diffusion, or isomorphism. While there are wonderful studies that use this approach to studying institutionalism, these studies are losing their prominence in institutional analysis.

Recently, there have been work focusing on institutional strategy (Lawrence, 1999), institutional entrepreneurship (DiMaggio, 1988; Suddaby and Greenwood, 2005; etc.) and institutional work (Lawrence and Suddaby, 2006). These concepts all share an interest in the more micro-processes of institutionalization. How do institutions compete for primacy in a new field? How do new practices become institutionalized? How are institutions created, maintained and disrupted? These are the new questions in institutional theory. Answers to these questions can be found by returning to the study of leaders. The argument is not that leaders are fully rational (or even boundedly rational) and make strategic decisions. The argument is that leaders do things, they make sense of the environment, and they are involved in the politics of organizational decisions and would represent a key part of the puzzle to understanding institutional phenomena. We argue that more work similar to that by Kraatz and Moore (2002) should be done. This type of work is also being called for in the leadership literature.

\section{CONCLUSION}

While we have focused on institutional leadership, we do not think all leaders are institutional leaders. Thus, we have two boundary conditions of institutional leadership. First, not all organizations are institutions. In addition to understanding institutional leadership, Selznick also informs of as to how we should study institutions.

The study of institution is in some ways comparable to the clinical study of personality. It requires a genetic and developmental approach, an emphasis on historical origins and growth stages ... Our 
problem is to discover the characteristic ways in which types of institutions respond to types of circumstances. The common-sense distinctions among enterprises according to whether they perform economic, political, religious, or military functions. (1957: 141-142)

We think that institutional and organizational theorists need to be more precise in describing the collective they are studying; what is it about a particular collective that leads one to call it an institution as opposed to an organization, group, practice, or association. Second, not all leaders of institutions are institutional leaders. Institutional leaders focus is on maintaining homeostasis. As opposed to institutional leaders, leaders of institutions (as well as leaders of organizations, associations, and practices) are characterized as administrators or managers, and their concern is with the technical core of the organization and its functioning.

We have argued that to infuse the organization with value, the institutional leader must do three things. First, they must management internal consistency. We suggest they do this through the telling of stories and the management of thematic coherence. Second, we argue that institutional leaders develop external supporting mechanisms that lead to increasing legitimacy of their organizations. They do this by serving as cognitive network brokers enabling a wide range of interaction inside and outside the organization. Third, institutional leaders must overcome external enemies. To do so, institutional leaders must defend against the death of existing practices, and prevent fragmentation of the population that originally institutionalized the practice.

Finally, we note that, despite the enormous intellectual contributions to understanding organizations, institutions, and leadership, Selznick has gone unnoticed by those who study leadership. We hope that as researchers start to focus on the leadership of organizations, rather than leadership in organizations, this will lead future leadership scholars to a rediscovery of his insights.

\section{BIBLIOGRAPHY}

Amason, A. C., \& Sapienza, H. J. 1997. The effects of top management team size and interaction norms on cognitive and affective conflict. Journal of Management, 23 (4): 495-516

Bedeian, A.G., \& Hunt, J.G. 2006. Academic amnesia and vestigial assumptions of our forefathers. The Leadership Quarterly, 17: 190-205.

Berger, P.L. \& Luckman, T. 1967. The social construction of reality. New York: Doubleday.

Berry, G. R. 2001. Telling stories: Making sense of the environmental behavior of chemical firms. Journal of Management Inquiry, 10: 58-73.

Biggart, N. W. \& Hamilton, G. G. 1987. An institutional theory of leadership. The Journal of Applied Behavioral Science, 23 (4): 429-441.

Birnbaum, R. 1990. How'm I doing? How college presidents assess their effectiveness. Leadership Quarterly, 1 (1): 25-39

Bluck, S., \& Habermas, T. (2000). The life story schema. Motivation and Emotion, 24: 121-147.

Boal, K. B., \& Schultz, P. 2007. Storytelling, time, and evolution: The role of strategic leadership in complex adaptive systems. The Leadership Quarterly 18: 411-428.

Boal, Kimberly B., \& Hooijberg, Robert J. Strategic leadership research: Moving on: Yearly review of leadership: A Special issue of The Leadership Quarterly, 11: 515-550.

Bolman, L.G., \& Deal, T.E. 2003. Reframing organizations: Artistry, choice, and leadership. 3rd edn. San Francisco: Jossey-Bass.

Brown, S., \& Eisenhardt, K. 1998. Competing on the edge: Strategy as structured chaos. Boston, MA: Harvard Business School Press.

Burt, R. 1992. Structural holes: The social structure of competition. Cambridge, MA: Harvard University Press.

Campbell, J. 1972. The hero with a thousand faces. Princeton, NJ: Princeton University Press and the Bollingen Foundation.

Carlson, S. 1951. Executive behaviour. Stockholm: Strombergs.

Czarniawska, B. 1997. Narrating the organization: Dramas of institutional identity. Chicago: University of Chicago Press. 
Daft, R.L. 2004. Organization theory and design. 8th edn. Mason, $\mathrm{OH}$ : Thomson South-Western.

DiMaggio, P.J. 1988. Interest and agency in institutional theory, in L.G. Zucker (ed.), Institutional patterns and organizations: Culture and environment. Cambridge, MA: Ballinger, pp. 3-22.

DiMaggio, P.J., \& Powell, W.W. 1983. The iron cage revisited: Institutional isomorphism and collective rationality in organizational fields. In W.W. Powell and P.J. DiMaggio (Eds.), The new institutionalism in organizational analysis: 6382. Chicago, IL: University of Chicago Press.

Dubin, R. 1979. Metaphors of leadership: An overview. In J. G. Hunt \& L. L. Larson (eds.), Crosscurrents in leadership, pp. 225-238. Carbondale, IL: Southern Illinois University Press.

Duffy, B.K., \& Carpenter, R.H. 1997. Douglas Macarthur: Warrior as wordsmith. Westport, CT: Greenwood Press.

Ellis, J., \& Moore, R. 1974. School for soldiers: West point and the profession of arms. New York: Oxford University Press.

Falla, J. 1981. NCAA: The voice of college sports. Mission, KS: National Collegiate Athletic Association.

Friedland, R., \& Alford, R.R. 1991. Bringing society back in: Symbols, practices, and institutional contradictions. In W.W. Powell and P.J. DiMaggio (eds.), The new institutionalism in organizational analysis, pp. 232-263. Chicago: University of Chicago.

Greiner, L. E. 2002. Steve Kerr and his years with Jack Welch at GE. Journal of Management Inquiry, 11, 343-350.

Greve, H. 1995. Jumping ship: The diffusion of strategy abandonment. Administrative Science Quarterly, 40: 444-473.

Grove. A. S. 1996. Only the paranoid survive. New York: Currency Doubleday.

Grove, A. S. 1997. Navigating strategic inflection points. Business Strategy Review, 8(3): 11-18.

Hacker, S. \& Washington, M. 2007. Pack leadership: lessons from the wild dogs of Africa. Milwaukee, WI: Quality Press.

Hirsch, P. 1986. From ambushes to golden parachutes: Corporate takeovers as an instance of cultural framing and institutional integration. American Journal of Sociology, 91: 800-837.
Hirsch, P. \& Lounsbury, M. 1997 Ending the family quarrel: toward a reconciliation of 'old' and 'new' institutionalisms, American Behavioral Scientist, 40: 406-18.

Hunt, J.G. 1999. Transformational/charismatic leadership's transformation of the field: An historical essay. The Leadership Quarterly, 10: 129-144.

Hunt, J.G., \& Dodge, G.E. 2000. Leadership déjá vu all over again. The Leadership Quarterly, 11: 435-458.

James, D.C. 1985). The years of Macarthur. Vol. III Triumph and disaster, 1945-1964. Boston, MA: Houghton Mifflin.

Kraatz, M. S. \& Moore, J. H. 2002. Executive migration and institutional change. Academy of Management Journal, 45 (1): 120-143.

Lawrence, T.B. 1999 Institutional strategy, Journal of Management, 25: 161-87.

Lawrence, T.B. \& R. Suddaby. 2006. Institutions and Institutional Work pgs 215-254, in S. Clegg, C. Hardy, W. Nord \& T.B. Lawrence (eds.), The handbook of organization studies. London: Sage.

Leblebici, H., Salancik, G.R., Copay, A., \& King, T. 1991. Institutional change and the transformation of the interorganizational fields: An organizational history of the U.S. radio broadcasting industry. Administrative Science Quarterly, 36: 333-363.

Lowe, K.B., \& Gardner, W.L. 2000. Ten years of the leadership quarterly: Contributions and challenges for the future. The Leadership Quarterly, 11: 459-514.

Meyer, J.W. \& Rowan, B. 1977. Institutionalized organizations: Formal structure as myth and ceremony. American Journal of Sociology, 83: 340-363.

Nutt, P. C. \& Backoff, R. W. 1997 Crafting a Vision. Journal of Management Inquiry 6(4): 308-328.

Oliver, C. 1992. The antecedent of de-institutionalization. Organization Studies, 13: 563-588.

Patterson, K. 2007. Creation and Evolution: The processes and strategies of institutional entrepreneurs in alternative medicine, 1896-2005. Ph.D. Dissertation in Management at Texas Tech University.

Pfeffer, J., \& Salancik, G. 1978. The external control of organizations: A resources dependence perspective. New York: Harper \& Row. 
Rao, H. 2002. Tests Tell: Constitutive legitimacy and consumer acceptance of the automobile: 1895-1912. New Institutionalism In Strategic Management Advances In Strategic Management: A Research Annual 19: 307-335.

Robbins, S.P., \& Judge, T.A. 2007. Organizational Behavior. 12th edn. Upper Saddle River, NJ: Person Prentice-Hall.

Scott, W. R. 1987. Organizations: Rational, natural and open systems. Englewood Cliffs, NJ: Prentice-Hall.

Scott, W.R. 2001 Institutions and organizations, 2nd edn. Thousand Oaks, CA: Sage.

Selznick, P. 1949. TVA and the grass roots. Berkeley: University of California Press.

Selznick, P. 1952. The organizational weapon. New York: McGraw-Hill.

Selznick, P. 1957. Leadership in administration: A sociological interpretation. New York: Harper \& Row.

Selznick, P. 1984. Leadership in administration. Berkeley, CA: University of California Press.

Schermerhorn, J.R., Hunt, J.G., \& Osborn, R.N. 2004. Core concepts of organizational behavior. New York: Wiley.

Shamir, B., Dayan-Horesh, H., \& Adler, D. 2005. Leading by biography: Towards a life-story approach to the study of leadership. Leadership, 1: 13-29.

Smith, R.A. 1988. Sports and Freedom: The Rise of Big-Time College Athletics. New York: Oxford University Press.

Stagg, P. 1946. The development of the National Collegiate Athletic Association in relationship to intercollegiate athletics in the United States. Unpublished Ph.D. Dissertation, New York University.

Stogdill, R.M. 1974. Handbook of Leadership: A Survey of Theory and Research. New York: The Free Press.
Strange, J. M., \& Mumford, M. D. 2005. The origins of vision: Effects of reflection, models, and analysis. The Leadership Quarterly, 16: 121-148,

Suchman, M. C. 1995. Managing legitimacy: Strategic and institutional approaches. Academy of Management Review, 20(3): 571-610.

Suddaby, R. \& Greenwood, R. 2005 'Rhetorical strategies of legitimacy', Administrative Science Quarterly, 50: 35-67.

Tengblad, S. 2004. Expectations of Alignment: Examining the link between financial markets and managerial work. Organization Studies, 25 (4): 583-606

Thomason, T. 1971. Bugle notes. 63rd edn. West Point, NY: United States Military Academy.

Washington,M. 2004. Field approaches to institutional change: The evolution of the National Collegiate Athletic Association 1906-1995. Organization Studies, 25(3): 1-25.

Washington, M. \& Ventresca, M. J. 2004. How organization change: The role of institutional support mechanisms in the incorporation of higher education visibility strategies 1874-1995. Organization Science, 15: 82-97.

Washington, M., Forman, P. F. Suddaby, R. \& Ventresca, M. J. 2005. Strategies and struggles over rules of the game: The governance of U.S. intercollegiate athletics 1950-1982. In K. Elsbach (ed.), Qualitative organizational research, 75-112. Greenwich, CT: Information Age Publishing.

Yukl, G. 2002. Leadership in organizations. 5th edn. Upper Saddle River, NJ: Prentice-Hall.

Zucker, L.G.1987. Institutional theories of organization. Annual Review of Sociology, 13: 443-464. 
